\title{
Women, Children and Violence in Aboriginal Law: Some Perspectives From the Southeast Queensland Frontier
}

\author{
Libby Connors
}

\begin{abstract}
Aboriginal writers, Jackie Huggins, Michael Dodson, Rosemary van den Berg, Lester Irabinna Rigby argue that the extent of research conducted in Aboriginal lands and on Aboriginal people since British invasion in the late 1770s, is so immense it makes us one of the most researched groups of people on earth ... Indeed, in some social science disciplines we are over-researched and this has generated mistrust, animosity and resistance from Aboriginal people. ${ }^{1}$
\end{abstract}

Unlike the other social sciences, and despite Henry Reynolds's call for historians to write the story of the 'other side of the frontier' more than 30 years ago, Australian colonial historians have been slow to take up the challenge of Aboriginal-centred history. Bound by the limitations of overwhelmingly white and unsympathetic source materials, attempting to interpret Aboriginal frontier actors is fraught with methodological difficulty for the historian. Scholarship on missions and reserves from later periods which have been able to draw on Aboriginal writing and oral history have been tackled with greater confidence and are now being supplemented by evocative histories by Aboriginal scholars, ${ }^{2}$ but Aboriginal frontier histories remain underdeveloped. Postcolonial approaches, with their interest in indigenous subjectivity, should have stimulated greater interest in Aboriginal views of the colonial past but here, too, the influence on Australian historiography has been mixed. Bain Attwood's book on the Batman treaty concluded that Aboriginal views of the 1830s were impossible to recover and so, only the Aboriginal protest movement of the 1970s was considered as

\footnotetext{
1 Karen L. Martin, 'Ways of Knowing, Ways of Being and Ways of Doing: A Theoretical Framework and Methods for Indigenous Re-search and Indigenist Research', Journal of Australian Studies, no. 76 (2003): 203. 2 Rachel Perkins and Marcia Langton, First Australians (Melbourne University Press, 2010). The literature on missions is too immense to cover here but Robert Kenny, The Lamb Enters the Dreaming: Nathanael Pepper and the Ruptured World (Melbourne: Scribe, 2007) is groundbreaking. Some of the best examples of reserve histories from Queensland include David S. Trigger, Whitefella Comin': Aboriginal Responses to Colonialism in Northern Australia (Cambridge University Press, 1992); Thom Blake, A Dumping Ground: A History of the Cherbourg Settlement (Brisbane: University of Queensland Press, 2001); Joanne Watson, Palm Island: Through a Long Lens (Canberra: Aboriginal Studies Press, 2010).
} 
part of the study of that important experiment of land purchase. ${ }^{3}$ The best work in the field of Aboriginal-centred colonial history has come from Sydney where Inga Clendinnen, Keith Vincent Smith and Grace Karskens have been prepared to interrogate and sift the white sources to recover Aboriginal voices and actions in histories that are deservedly celebrated for their multi-layered and vivid retelling of colonial foundations. ${ }^{4}$

The task, however, is not easy and it presents formidable methodological problems, as Aboriginal and history critics have highlighted. This chapter uses some of the evidence from Moreton Bay to respond to some of the more complex and controversial aspects of traditional law that have surfaced in the Sydney histories, regarding the level of violence directed at wives and children. It briefly outlines some of the criticisms that have been made of Clendinnen's Dancing with Strangers (2003), notes how Karsken's The Colony (2010) overcomes some of the earlier work's limitations but also where it concurs regarding some contentious aspects of Eora society; it then briefly outlines the evidence from Moreton Bay regarding just two aspects of traditional society - Aboriginal marriage and attitudes to children - before drawing some conclusions about contextualising traditional law in Australian historiography.

Despite its deserved celebration for recovering the importance of Bennelong's role as a cross-cultural diplomat and negotiator in the founding of New South Wales, Dancing with Strangers was subject to staunch criticism from Aboriginal scholars, one of whom argues that it 'render[s] invisible and dematerialise[s] contemporary flesh-and-blood Aborigines'. ${ }^{5}$ There was concern about Clendinnen's portrayal of gender relations as being marked by excessive violence. ${ }^{6}$ It was argued that an effect of the work was to reproduce a view of Aboriginal women as the abject beasts of burden that was so favoured by nineteenth-century anthropology, a representation well and truly rejected by anthropologists by the 1980s. ${ }^{7}$ Another concern was that its timing affirmed a right-wing representation of Aboriginal community dysfunction that justified

3 Bain Attwood (with Helen Doyle), Possession: Batman's Treaty and the Matter of History (Melbourne: Miegunyah, 2009).

4 Inga Clendinnen, Dancing with Strangers (Melbourne: Text, 2003); Keith Vincent Smith, Bennelong: The Coming in of the Eora: Sydney Cove 1788-1792 (Sydney: Kangaroo Press, 2001); Vincent Smith, King Bungaree: A Sydney Aborigine Meets the Great South Pacific Explorers, 1799-1830 (Sydney: Kangaroo Press, 1992); Vincent Smith, Wallumedegal: An Aboriginal History of Ryde (Sydney: Ryde City Council, 2005); Grace Karskens, The Colony: A History of Early Sydney (Sydney: Allen and Unwin, 2010).

5 This is part of Philip Morrissey's critique of Inga Clendinnen's Dancing with Strangers. See Philip Morrissey, 'Dancing with Shadows: Erasing Aboriginal Self and Sovereignty', in Sovereign Subjects: Indigenous Sovereignty Matters, ed., Aileen Moreton-Robinson (Sydney: Allen and Unwin, 2007), 69.

6 Clendinnen, 146-51, 159-67.

7 See Les Hiatt's summary of the anthropological debates on the status of women in L.R. Hiatt, Arguments about Aborigines: Australia and the Evolution of Social Anthropology (Cambridge University Press, 1996), 5763; Nancy M. Williams and Lesley Jolly, 'From Time Immemorial? Gender Relations in Aboriginal Societies before "White Contact"', in Gender Relations in Australia: Domination and Negotiation, eds, Kay Saunders and Ray Evans (London: Harcourt Brace Jovanovich, 1992), 9-19. 
the Northern Territory Intervention, as introduced by the Liberal government of John Howard. Shoni Konishi contends that the problem lay in Clendinnen's failure to consider how the assumptions and values of late-eighteenth-century ideas about civilisation infused the writings of the First Fleet officers; these works on which the author placed so much reliance were unreliable as they sought to represent Aboriginal gender relations as the polar opposite of that valued by refined and civilised late-eighteenth-century gentlemen. ${ }^{8}$

Karskens avoids such a reductionist view of traditional society by covering the broader span of Aboriginal individuals and communities over time, rather than telescoping on moments of internal discord. Karsken's does not reject the white primary sources, with their collaborating data, but better contextualises them so that conflict and brutality, by both white and black individuals and communities, can be understood as cause and effect, heightened by new geographies. Nonetheless, the description of domestic discord and an incident of murderous payback carried out upon a six- or seven-year-old girl repeats evidence that is also presented by Clendinnen and disturbs the representation of the apparent integrity of Aboriginal law. ${ }^{9}$ It is this which needs to be critically examined by looking at the comparable evidence from other parts of the continent.

Part of my original interest in the topic of indigenous women in southeast Queensland was stimulated by the contrast with the circumstances of indigenous women in Sydney. The primary sources are derived from a period 30 to 50 years later and, unfortunately, they are not as extensive as those produced by the members of the First Fleet. There are, however, a number of sympathetic sources that offset the official and antagonistic settler documents. While none of these sources is flawless - the main counter-discourse came from missionaries who were bound by their own cultural assumptions of Christian moral superiority they provide a contrast that allows a more balanced reconstruction of the events of the frontier period. Fortunately, the European sources are supplemented by the knowledge of Gaiarbau, a member of the Jinibara or Dalla ${ }^{10}$ who, as a man in his 80 s, related a great deal of information about traditional life to L.P. Winterbotham between 1950 and $1957 .{ }^{11}$ The result is some intimate information that is, albeit, still very fractured by being embedded in the male perspective.

8 Shino Konishi, “"Wanton with Plenty": Questioning Ethnohistorical Constructions of Sexual Savagery in Aboriginal Societies, 1788-1803', Australian Historical Studies 39, no. 3 (September 2008): 356-72.

9 Karskens, 442, 460.

10 Gaiarbau gave the name of his people as 'Jinibara' but I have generally used the term 'Dalla' as it and 'Gubbi Gubbi' are the names by which the traditional owners of the Blackall Ranges identify today. Where possible I have used the names for traditional owners as given by the Foundation for Aboriginal and Islander Research Action, but the missionaries' nomenclature does not always match that in use today, and historic terms are retained to minimise confusion.

11 Gaiarbau's story of the Jinibara tribe of southeast Queensland (and its neighbours). Collected by L.P. Winterbotham, MS 45 / MS 429, Australian Institute of Aboriginal and Torres Strait Islander Studies (AIATSIS). 
The stereotype of Aboriginal brutality towards wives, as promulgated by sources based around Sydney, had become so entrenched in colonial discourse that the marooned convicts who gave us the first recorded evidence of gender relations in the north were taken aback by the level of sympathy and affection shown between husbands and wives. At the same time, they recorded women's participation in communal meetings and group fights, which, along with other evidence, confirm women's ready engagement in hand-to-hand combat. Clendinnen's and Karsken's use of the term 'warrior culture' seems the best way to categorise this aspect of hunter-gatherer society for a modern audience.

One of the earliest accounts from the Moreton Bay region comes from John Uniacke, a member of the crew that accompanied surveyor-general John Oxley in 1823. Left on board the main vessel moored near Bribie Island while Oxley went exploring up river, Uniacke was in a position to record discussions with rescued shipwreck survivors Thomas Pamphlet and John Finnegan, who had been living with traditional owners around the bay for several months. Their accounts challenged the prevailing view of female subjugation in Aboriginal society:

The women are far more fortunate than those in the neighbourhood of Sydney, where they are abused in the most cruel way by the men, and where the marriage ceremony consists of seizing the bride and beating her till she is senseless. Pamphlet assured me that, during his residence among these natives (nearly seven months) he never saw a woman struck or ill treated except by one of her own sex ... The women that I saw were far superior in personal beauty to the men, or, indeed, to any natives of this country whom I have yet seen. Many of them are tall, straight, and well-formed. ${ }^{12}$

Oxley's party had arrived in Pumicestone Passage, on the northwest side of Moreton Bay, just two days after a major meeting had taken place to settle intertribal matters, a circumstance that allowed Finnegan to give Uniacke a fresh and vivid account of proceedings. He related how, after two days' travel he, and the tribe by which he had been adopted, arrived at the meeting place where the participants 'were so numerous, that I could hardly count them ... (for there were many tribes assembled to see the fight)'. The contests - for this was an opportunity to settle a number of outstanding grievances, not just a dispute between 'two tribes' as Finnegan had expected - took place about two and a half kilometres from the village and encampment; there 'the multitude' assembled around the perimeter of a specially constructed large sunken pit. The first fight Finnegan was permitted to witness was between two women:

12 Uniacke's narrative of Oxley Expedition 1823 cited in J.D. Lang, Cooksland in North-Eastern Australia (London: Longman, Brown, Green and Longmans, 1847), 410. 
I there saw a woman of my tribe, and one of another, fighting desperately with sticks. The battle did not, however, last long, as they appeared to be quite in earnest, and in five minutes, their heads, arms, etc, being dreadfully cut and swelled, our woman was declared the conqueror, the other not being able any longer to oppose her. The victory was announced by a loud shout from all parties, and the Amazonian combatants were immediately carried away by their respective friends. ${ }^{13}$

Pride in one's kin group, physical prowess and personal bravery were prized as much by the women as by the men; there was no point in a woman initiating a legal challenge if she was not prepared to stand her ground forcibly. This 'Amazonian' culture, shocking to European observers, was an intrinsic part of life and the system of law in southeast Queensland. Finnegan's account made clear that the fights were supervised and governed by rules of fair play, with a halt called to proceedings when those rules were deemed to have been breached. Tom Petrie, who had travelled and periodically lived with local Aboriginal people since a small child, also told his daughter of how women not only fought to settle disputes, but would sometimes contribute to major battles between their menfolk from the outer fringes. ${ }^{14}$

Women with childcare responsibilities were not spared the tensions of these contests but had to be prepared to retreat with the children and give up their ground in the event of their men being routed. Finnegan gave a personal example of this as his lack of bushcraft left him at a decided disadvantage at this great fight. The Bribie Island 'chief' who had accepted him into his tribe insisted on introducing Finnegan to the other chiefs; he needed to gain a commitment from the other tribes not to molest Finnegan should the Bribie Islanders not prevail. Indeed, the fight did go against the Bribie Islanders and Finnegan was forced to withdraw with the women and children. He was unable to keep up with his companions, however, and his lack of bushcraft soon saw him surrounded by the Bribie Islanders' opponents, who laughed at him as they overtook him. ${ }^{15}$

Some 18 years later, but still before the opening of the district to settlement, two of the German missionaries who had established a mission at Nundah in 1838, were invited by the local Aboriginal people to travel with them to a fight and festivities for several groups of traditional owners. They came from across the region to gather at Toorbal, on the northwest side of Moreton Bay. Like Finnegan

13 'Account of a Fight Among the Natives of Moreton Bay Witnessed by John Finnegan' cited by Lang, ibid., 411-15.

14 Constance Campbell Petrie, Tom Petrie's Reminiscences of Early Queensland (Melbourne: Lloyd O'Neil, 1975 [facs of 1904]) 46.

15 'Account of a Fight Witnessed by Thomas Pamphlet' cited in Lang, 410-11, 413-14. 
before them, the missionaries were aghast at the ferocity of the women's formal contests. Reverend Christopher Eipper wrote a description for their Presbyterian supporters in Sydney, which was printed in the Colonial Observer:

In the afternoon our attention was suddenly arrested by a great noise, caused by beating sticks together, and as we saw all the women run with their long and pointed sticks, which are used in digging dangum; we ran also to ascertain what this meant. But what a scene did we behold! The whole of the women were engaged in a regular battle; it was quite overwhelming to look at this fight of women, than which no contest of men could be fiercer; some actually had froth before their mouth. Each had her antagonist, who parried her blow by holding her stick between her fingers over her head; and then immediately returned the stroke, which was parried in the same way; when they got close together, they took hold of one another, each endeavouring to throw the other down.

'Some had their fingers and elbows bleeding when we arrived'; Eipper continued and so the two young missionary men sought to disrupt the fight, much to the annoyance of the older women who 'were very much displeased, and pointed their spears at ours; yea one threw it at Mr E'. Not only did the young Christians fail to understand the authority of the older women, they also failed completely to understand a warrior culture in which it was accepted that disputes were settled by resort to arms. The next morning they were shocked to see two women fighting 'whose husbands were quietly looking on ... we separated them, threatening that we should tell the Commandant of their quarrels' ${ }^{16}$

A culture based on warrior values was also much more accepting of informal violence between men and women and between husbands and wives than contemporary standards allow. Unlike the castaways, the German missionaries did witness incidents of domestic violence but seemed as much struck by the women's vocal objections to their treatment as by the assaults. This warrior culture was oral as well as physical and one reason for the 'froth before their mouth', as Eipper had phrased it, was that challenges and fights were preceded by the angry public issuing of a complaint and challenge followed by verbal jousting which sometimes averted a physical showdown while, at other times, it heralded the onset of a fight in earnest. ${ }^{17}$ On one occasion the missionary Niqué recorded how a woman, who was knocked down by a man after she provoked him, was not only not submissive, but continued to challenge him by singing

16 Colonial Observer, 21 October 1841, 23.

17 'Such was the eagerness of all to listen to what was spoken on such occasions, that whenever any one was heard to speak in that way after the evening meal had been taken, we scarcely could get any information from our neighbours or guides of the cause of the quarrel'. Colonial Observer, 14 October 1841, 10. 
a war song at him for 'about half an hour' ${ }^{18} \mathrm{~A}$ vocal wife also reprimanded her husband at length when he struck her for eating his roast potato, a new delicacy courtesy of the missionary guests. ${ }^{19}$

A scolding is obviously not as effective an expression of power as physical force but it would be wrong to assume female subjection as a result. The missionaries were struck by the desire of the men to impress their women, and the obvious affection between married couples that was often displayed. On one of their excursions to Toorbal, young Ningy Ningy guides escorted the missionaries over to 'Yarun', the local name for Bribie Island. Circumstances forced them to stay overnight but, before returning to their own village, Eipper recorded that 'as the [Ningy Ningy] were young men they were very particular to dress themselves carefully before they made their appearance again in the camp, significantly replying to our enquiry, why they did so, the ladies will see us' ${ }^{20}$ Anthropological work has established that the system of betrothals worked in the interests of the older men and women and increased competition among young men and unbetrothed females for the prize of a marriage partner. ${ }^{21}$

One of the most important contributions from the missionaries is the context for some of the violent exchanges that they witnessed, and how traditional society managed violence and set limits on its expression. The young German evangelists worked closely with Deciby, a Ningy Ningy man whom they referred to as the 'King of Toorbal' and who frequently stayed at the group of cottages the missionaries constructed for their regular indigenous visitors. The camp and gardens - known by a local name of Girkum - were on the other side of Kedron Brook, opposite the missionaries' own thatched cottages and planted fields. Clearly a man of some stature, Deciby was an important diplomatic gobetween for the missionaries and many of the traditional owners to the north of Brisbane. Deciby's standing was presumably also high among the women because, although he had a wife and a newborn son, he committed adultery with the wife of Wogan, a prominent local man who was well-known in Brisbane and at the mission. ${ }^{22}$ When informed of his wife's actions, Wogan approached

18 Journal of the Brethren Niqué \& Rodé who were Itinerating Among the Natives at Umpie Boang from the 12 of March to the 31st 1842, entry for 25 March, Lang Papers Mitchell Library (ML).

19 Colonial Observer, 28 October 1841, 27.

20 Colonial Observer, 21 October 1841, 23. Emphasis in original. This report also included discussion of a man's great concern for his sick wife; other references to spousal affection or concern are evident in Colonial Observer, 11 November 1841, 42 and 'Mission Diary', entry for 15 January 1842, Lang Papers, ML.

21 Hiatt, 67-71 covers the debates concerning benefits to mothers-in-law of the bestowal system.

22 Wogan was well known in Brisbane and Ipswich and featured regularly in newspaper reports after 1842. He may have been an elder since the missionaries referred at times to the 'Wogans' meaning a number of other men who may have been his tribal or biological brothers. It is not clear from any of the accounts whether he was Yaggera, Turrbal or Ningy Ningy and his ready movement between Girkum, Toorbal and Brisbane indicate the high level of interaction between the Brisbane, Ipswich and Bayside peoples. For other references to Wogan see Colonial Observer, 14 October 1841, 10; 28 October 1841, 27; 18 November 1841, 51; Sydney Morning Herald, 7 April 1846, 3; Lang, 398-99. 
the camp late one summer night to confront Dambir Dambir, his wife, but he did not go alone. He brought with him his brother, Borungado. Wogan found his wife and brought her to his own hut where he was armed with his club and shield; Dambir Dambir was also prepared with her digging stick, which she used to shield herself from her husband's blows. Wogan, however, soon knocked her to the ground at which point 'all the women' of the camp intervened, shielding Dambir Dambir from the blows of the waddies of Borungado and Wogan with their sticks. The missionaries believed that, if they left the scene, Wogan and Borungado intended to kill Dambir Dambir, although it is not clear how this could have been accomplished given the role of the other women of the camp. ${ }^{23}$

Was this normal women's business to intervene to protect Dambir Dambir, or was Dambir Dambir fortunate to have her tribal sisters there that night? Gaiarbau gave another revealing account of how marital cruelty was managed. He assigned key roles not to the women of the tribe but to the victim's mother and her brother. According to Dalla protocol, a secret message was sent to the headman of the wife's tribe; the headman then organised for her brother to bring her back to her family. The brother had to carry a specially painted spear, which was adorned with the white cockatoo feather that had been presented to the girl's mother upon her marriage. The headman of the husband's tribe, upon seeing the brother, would allow him to approach his sister. If she took the spear she would be led away to her own people where it then became the responsibility of her brothers to maintain her. This system was essentially a form of divorce, for the wife was required to leave behind any children and neither husband nor wife were permitted to remarry during the other's lifetime. Social harmony prevailed, however, for according to Gaiarbau, 'All this was done by consent of the Bora and caused no fight'. ${ }^{24}$ So it would be unfair to characterise Dambir Dambir's assault as typical since there were formal mechanisms to protect wives. Despite the pre-eminence of fighting skills in traditional culture, women's security was safeguarded through their kin and through women's culture.

The descriptions of women's fighting and their lack of subservience to husbands mirror the Sydney material closely. What is new are the insights from Gaiarbau that, in the north at least, there were formal processes for limiting spousal violence. The lack of similar practice in Sydney could be a result of the smallpox epidemic's impact on local traditions, a local variation peculiar to southeast Queensland, or a bias of the extant sources.

It raises similar uncertainties over the interpretation of the apparent payback killing of the six- or seven-year-old female child near Sydney Domain in

23 Monday 7 - Tuesday 8 March 1842, Extracts from the Diary of the German Mission to the Aborigines at Moreton Bay from the 25th December 1841 to the 13 of May 1842, Lang Papers, ML.

24 Gaiarbau's story of the Jinibara tribe of southeast Queensland (and its neighbours). Collected by L.P. Winterbotham. MS 45 / MS 429, AIATSIS, 29-30. 
circa 1795-96, which also indicates starkly different relationships to those in existence at Moreton Bay. In reports of their northern journeys, the German missionaries had commented on the evident affection for children that was displayed by the traditional owners. The tears shed by Aboriginal fathers, uncles and grandfathers on being reunited or parting from small children indicates demonstrative affection for children was a part of everyday manners in southeast Queensland. ${ }^{25}$ Furthermore, traditional law enforced respect for infant dead to the full extent. In 1829 the convict runaway, James Davis, witnessed the lawful killing of his companion John Downes who had emptied a dilly he had found in a tree of its bones. After long communal debate the coastal tribe insisted on full punishment for his sacrilege, for he had disturbed the bones of a dead child. ${ }^{26}$

Gaiarbau outlined the system of discipline for children as it operated in the 1870s, and later, in his interview with Winterbotham. A mother and her brothers were responsible for the oversight of children; a common chastisement was to be hit on the legs with sticks which is consistent with Petrie's story of the 'beating' of his youthful companion Wamgul by a 'gin'. ${ }^{27}$ When a mother's or uncle's rebuke proved to be insufficient, the mother could appeal to the tribal council, which would enforce the 'smoking' of the child to drive out the evil spirit that was presumed to be responsible for the behaviour. It was a ritual that was also applied to adults and, according to Gaiarbau, thoroughly scared children, who lived in dread of it. ${ }^{28}$

There is no mention of payback applying to children and Gubbi Gubbi oral history affirms that it was unheard of. ${ }^{29}$ From February 1842, in the aftermath of the mass poisoning at Kilcoy Station, a pattern of Aboriginal payback can be identified across the region, culminating in a mass attack on Gregor's Station near Caboolture in October 1846. This attack caused outrage in Brisbane, for it was the first time that a white woman, Mary Shannon - a female servant, who was killed alongside her pastoralist employer, Andrew Gregor — had been the victim of an Aboriginal attack in the north. Perhaps more remarkable, however, was that none of the four children, all under 11 years of age, who lived on the station were harmed. ${ }^{30}$ Under a system of payback it would seem logical that children might be seen as a target for law enforcement, given that Aboriginal

\footnotetext{
25 See entry for 10 June 1842 in Karl W. Schmidt, Report of an Expedition to the Bunya Mountains in Search of a Suitable Site for a Mission Station (Translated by Dr L. Grope and edited and notated by P.D. Wilson, F.S. Colliver and F.P. Woolston), Acc. 3522/1 and 3522/2, Box 7072, John Oxley Library; also Journal of the Brethren Eipper and Hausmann During their Residence at Umpie Boang from 22nd November to 3rd December 1842, entry for 23 November 1842, Lang Papers, ML.

26 Lang, 420; Brisbane Courier, 27 October 1923, 19.

27 Petrie, 143-45.

28 Gaiarbau, 78.

29 Discussion with Gubbi Gubbi community historian and descendant of Dalaipi, Alex Bond, 26 February 2011.

30 For an account of the attack see Libby Connors, 'A Wiradjuri Child at Moreton Bay', Queensland History Journal 20, no. 13 (2010): 775-86. Ten-year-old Aboriginal boy, Ralph Barrow, and the three daughters of Thomas and Mary Shannon, five-year-old Margaret, four-year-old Mary Ann and two-year-old Eliza, were living on the station in 1846 .
} 
children were reported to be among the dead at Kilcoy, ${ }^{31}$ but here they were consciously excluded from violence, despite a score or more of Aboriginal people raiding the station while the only remaining adult station worker fled for his life.

There was one attack on a white child by two Aboriginal men in Ipswich in April 1843 that needs to be considered in this context. The two-year-old child of a blacksmith went missing and her body was found, badly mutilated, six days later. From February to April 1843 there had been payback attacks on Kilcoy, Durundur and Eales stations but, other than the timing, these were markedly different adult-male-to-adult-male situations, comprising surprise spearings that were undertaken with local Aboriginal support. This attack on a child did not have local Aboriginal support: Aboriginal women, unaware of the intentions of Jacky Jacky, one of the perpetrators, had called out to him and his accomplice Peter when they abducted the child, been aggressively rebuffed and then reported them to the police. This suggests that there was no communal discussion of grievances, no agreed guilty party and no agreement about an appropriate punishment, all of which were standard features of local payback deliberations. The Sydney Morning Herald report gives only one hint - it described Jacky Jacky as 'the complete terror of his tribe'. ${ }^{32}$ Jacky Jacky may have been a feared medicine man, a gundir in the language of the Dalla, and the murder of the child part of an act of sorcery, although this interpretation does not fit easily either. The gundir or 'medicine man' held great power and esteem. In southeast Queensland, the position was not confined to men for Gaiarbau knew of three women who had held this post. ${ }^{33}$ The awe and authority held by these 'doctors' was described by Petrie who gave the Turrbal name as 'Turrwan'. ${ }^{34}$ Because they had the power to use magic for good or ill, to bring rain and storms and to set a curse upon an enemy and to release them from it, gundir contributed an emotional and spiritual aspect to the intertribal politics of the region that often left them outsiders, people apart. ${ }^{35}$

It is possible to reconstruct historical events to provide Jacky Jacky with cause - there is documented evidence of his grievances with a convict who had taken an Aboriginal woman from Oxley Creek to the penal settlement in

\footnotetext{
31 Only three individual victims of the poisoning were ever identified - the three sons of Pamby Pamby, who had adopted Davis into his tribe. Davis and Bracewell both reported to Commissioner Simpson that women and children were among the victims. Commissioner Simpson to Colonial Secretary, 30 May 1842, Return of Mr Petrie from Excursion to the North, letter no. 42/4284 in CSIL: Moreton Bay 1842, 4/2581.2, 30 May 1842, Return of Mr Petrie from Excursion to the North, letter no. 42/4284 State Records of New South Wales (SRNSW).

32 Sydney Morning Herald, 19 April 1843, 3; entry for 25 January 1843, General Diary of the German Mission from 23 January to 18 July 1843, Lang Papers, ML.

33 Gaiarbau, 52.

34 Petrie, 29-30; see also Uniacke in Lang, 408.

35 Gaiarbau, 51-5; Petrie, 29-30.
} 
December $1841 .^{36}$ The readiness with which Aboriginal information was given to the Ipswich police, however, and with which Jacky Jacky and Peter were surrendered, all suggest the killing was not sanctioned by the Yagerra.

As we struggle to reconstruct the processes of communal decision-making from brief and fragmented source material, the difficulty of interpreting situations such as the death of the blacksmith's child at Ipswich or the young Aboriginal girl in the Domain will arise again. Without the brief references to Aboriginal opposition to Jacky Jacky's attack in a Sydney Morning Herald report, the circumstantial evidence would have weighted an interpretation favouring payback. Construing the brutal death of a European child as an act of Aboriginal law in its historical context is not impossible: just as on the Cumberland Plain, night raids on camps of unsuspecting Aboriginal families by white settlers became more frequent in the decade following the opening of the northern region in May 1842, although the first openly admitted case in which an Aboriginal child and three women were killed was not until November $1848 .^{37}$ Where on such raids children were not killed outright but orphaned, we have accounts of Europeans returning home with Aboriginal children who became the first of many informal stolen generations, long before any official policy was in place in the twentieth century. Shirleene Robinson has sought to identify as many of these children in Queensland as possible and the unfree and unpaid conditions under which many of them survived. ${ }^{38}$

We could just as easily further historicise such retaliatory conduct by Jacky Jacky with reference to the excesses of the British criminal justice system between 1788 and 1840. The age of criminal responsibility was just seven years in the eighteenth century, and remained at eight years of age in British law until 1963 when it was raised to ten. ${ }^{39}$ Children as young as seven were subject to the severity and callousness of a legal system that included execution, although most of these children escaped the gallows ${ }^{40}$ only to find themselves transported

\footnotetext{
36 Andrew Evans: Charged with Disobedience of Orders and Neglect of Work, 21 December 1841, Book of Trials, Queensland State Archives.

37 Commissioner Rolleston on the Darling Downs reported the incident and his inability to find a single witness who would identify those responsible. Commissioner Rolleston to Colonial Secretary, 28 November 1848, L/no. 48/14088 and enclosure in CSIL: 1848 CCL (2) 4/2812 SRNSW.

38 Shirleene Robinson, Something like Slavery: Queensland's Aboriginal Child Workers, 1842-1945 (Melbourne: Australian Scholarly Publishing, 2008).

39 'The Age of Criminal Responsibility in England and Wales', House of Commons Library, Standard Note, SN/HA/3001, p. 2. Available at: http://www.parliament.uk/briefingpapers/snha-03001.pdf accessed 26 February 2011.

40 Michael Stern and Richard Clark are attempting to catalogue all children and youths hanged in Great Britain from the seventeenth to the twentieth centuries on their Capital Punishment UK website. See: http:// www.capitalpunishmentuk.org/child.html accessed 26 February 2011.
} 
to New South Wales. ${ }^{41}$ Contextualising British law's cruel indifference to the plight of the child serves to undercut any accusation of reproducing anew a colonial discourse of the savagery of traditional society.

Such contextualisation is not necessary in the case of the attack on Moore's child because the evidence, although light, points in the opposite direction towards an assault that was unsanctioned by Jacky Jacky's Yaggera people. The evidence from the north suggests that Aboriginal law was far better at protecting its people from excessive cruelty than British law of the same era. As historians reconsider the colonial sources to tell Aboriginal-centred histories of the frontiers, broader patterns of traditional ways of managing one another, outsiders and intruders will be discerned. Perhaps then we will be able to explain the 'stable core, a sense of rightness in one's skin' ${ }^{42}$ that marks the persistence of Aboriginal identity and Aboriginal ways of viewing the world through such immense change. Close and critical reading of existing flawed primary sources can de-centre European interests and concerns and shift the critical gaze to the unnamed women who fill their background. The integrity of women's lives in traditional society is a useful starting point for this venture into the realm of Aboriginal sovereignty.

\section{Acknowledgments}

This paper draws in part on work published in 'Women on the South-East Queensland Frontier', Queensland Review 15, no. 2 (2008): 19-37.

\footnotetext{
41 Robert Holden has identified three convicted children on the First Fleet, six aged between nine and 12 years of age on the Second Fleet, and five sentenced to transportation as late as 1837 (Robert Holden, Orphans of History (Melbourne: Text, 1999), 3, 22).

42 Karskens, 435.
} 